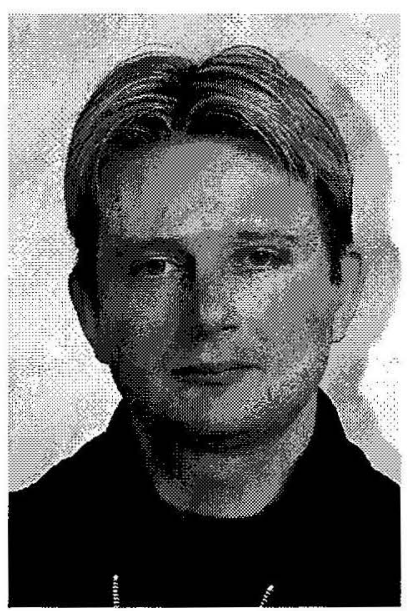

\title{
THE INFLUENCE OF MACRO TRENDS ON THE FREQEUNCY OF INDUSTRIAL DISPUTES
}

\author{
Glen Thickett \\ Victoria Management School \\ Victoria University of Wellington
}

\section{Introduction}

Industrial disputes are costly. In a protracted dispute the cost of a strike or lockout is often greater to both parties than benefits gained once the dispute is resolved. This paper investigates the literature on the influences and causes of industrial disputes and applies this information to ascertain the influence of macro-variables on industrial stoppages in New Zealand. The period of this analysis begins in the years prior to the introduction of the Employment Contracts Act and concludes with the first fifteen months of the Employment Relations Act.
\end{abstract}

Abstract

New Zealand, like many other nations has seen a dramatic fall in both the frequency and length of industrial disputes since the highs of the 1970s and early 1980s. This paper investigates and assesses the influence of aggregate economic and labour market conditions, and the resultant effects of those conditions, on the scale and scope of industrial disputes in New Zealand between 1988 and 2001. To this end, the purpose of this paper is to determine the influence of the prevailing legislation; the decline in union density and the relative strength of unions in each industry; and the importance of economic growth, wages and inflation on the length and frequency of industrial disputes.

This period saw great change in the number of industrial stoppages. There were 172 stoppages in 1988 , resulting in 381,710 person days of work lost. In the year to 2001 , the number of disputes had fallen to 42 , just a quarter of the 1988 figure. Likewise in 2001 there were 54,440 person days of work lost from stoppages -86 percent fewer than the comparable 1988 figure. The purpose of this paper is to investigate reasons for this fall. To this end, this paper examines union membership and density, change in wages and inflation, Gross Domestic Product and the influence of the Employment Contracts Act to determine whether they have had an influence on the decline in the number of disputes over the past fourteen years.

Table 1: Industrial Disputes in New Zealand 1988 - 2001

\begin{tabular}{l|crrrrc}
\hline Year & Total Disputes & $\begin{array}{c}\text { Number of } \\
\text { Lockouts }\end{array}$ & $\begin{array}{c}\text { Number of } \\
\text { Employees Involved }\end{array}$ & $\begin{array}{c}\text { Person Days of } \\
\text { Work Lost }\end{array}$ & $\begin{array}{c}\text { Average Days } \\
\text { Lost Per Worker }\end{array}$ & $\begin{array}{c}\text { Approx Loss in } \\
\text { Wages \$(000) }\end{array}$ \\
\hline 1988 & 172 & 0 & 103,981 & 381,710 & 3.7 & 32,632 \\
1989 & 171 & 0 & 78,921 & 193,308 & 2.4 & 18,763 \\
1990 & 137 & 1 & 50,007 & 330,923 & 6.6 & 48,433 \\
1991 & 71 & 3 & 51,962 & 99,032 & 1.9 & 11,577 \\
1992 & 54 & 7 & 26,803 & 113,742 & 4.2 & 19,372 \\
1993 & 58 & 5 & 21,303 & 23,770 & 1.1 & 2,863 \\
1994 & 69 & 6 & 16,042 & 38,262 & 2.4 & 4,580 \\
1995 & 69 & 2 & 32,048 & 53,352 & 1.7 & 6,813 \\
1996 & 72 & 3 & 42,307 & 69,514 & 1.6 & 9,768 \\
1997 & 42 & 2 & 7,646 & 24,616 & 3.2 & 3,126 \\
1998 & 35 & 1 & 15,205 & 11,778 & 0.8 & 1,887 \\
1999 & 32 & 1 & 10,747 & 16,674 & 1.6 & 3,343 \\
2000 & 21 & 0 & 2,632 & 11,495 & 4.4 & 2,272 \\
2001 & 42 & 2 & 22,022 & 54,440 & 2.5 & 7,682 \\
\hline
\end{tabular}

Source: Statistics New Zealand Labour Market Statistics (various years) 
As illustrated by Table 1, there are a number of possible ways to measure the number of industrial disputes. Total disputes, for example, records the total number of stoppages in a year. This includes both full and partial strikes (such as a 'go-slow', 'work to rule' or 'overtime ban') and lockouts. Between 1988 and 2001, the number of number of total stoppages fell from 172 in 1988 to a mere 21 in 2000 and 42 in 2001 . This is extremely low in comparison to the late 1970s, when the highest number of stoppages was recorded - 562 in 1977. Also of note, lockouts have been a comparative rarity in New Zealand, with the figure never reaching double figures during this period of analysis.

Alternatively, stoppages can be measured by the number of employees involved in industrial disputes. Table 1 shows that this peaked in 1988 at 103,981 employees and has since fallen to less than a quarter of that level in 2001. This figure however, includes employees who are not directly involved in the industrial dispute; for example, it includes non-striking employees who are unable to carry out their normal duties because of a stoppage.

The number of person days of work lost from industrial disputes is calculated from the number hours not worked by striking or locked out employees and then converted into a standard eight hour day. This indicator of industrial disputes has fallen considerably over the period of this analysis from a high of 381,710 in 1988 to a low of 11,495 in 2000. Interestingly, however, the number of person days lost per worker involved in an industrial dispute has remained relatively stable over the period examined, with usually between one-and-a-half and fourand-a-half days of work lost per employee. Corresponding with the fall in the number of disputes in New Zealand is a large reduction in the value of lost wages and salaries from a high of $\$ 48.4$ million in 1990 to $\$ 2.3$ million in 2000 . This however, does not take into account the fact that employees may 'catch-up' on work not carried out once the dispute is resolved.

Accordingly, there are several different indicators of industrial disputes available to be analysed. The regressions in this paper employ two indicators of industrial disputes. First, the total number of disputes but given that we cannot determine the length of these stoppages, later regressions use person days of work lost from industrial disputes as the dependent variable.

So what has happened in the last decade and a half that could have caused the number of disputes to fall at such a rapid rate? The fall may in part be attributable to the introduction of the Employment Contracts Act in 1991. The Employment Contracts Act ended union monopoly rights over industrial relations matters; promoted individual employment contracts over collective arrangements; contributed to a collapse of multi-employer bargaining and a reduction of collective bargaining coverage; and saw a 50 percent reduction in union membership. The Employment Contracts Act also greatly diminished the power of unions to operate. This is not surprising given that the Act did not use the word 'union' at any point. Essentially, the Employment Contracts Act irrevocably changed the nature of the industrial relations system in New Zealand. This change is observable in Figure 1, which shows the fall in union density throughout the 1990s and that this fall is matched by a fall in the number of industrial disputes.

The Employment Relations Act has since replaced the Employment Contracts Act. The new Act promotes collective bargaining and 'good faith' employment relations. Essentially, it represents a notable shift away from the approach taken by the Employment Contracts Act.

Figure 1: Disputes and Union Density 1988 - 2001

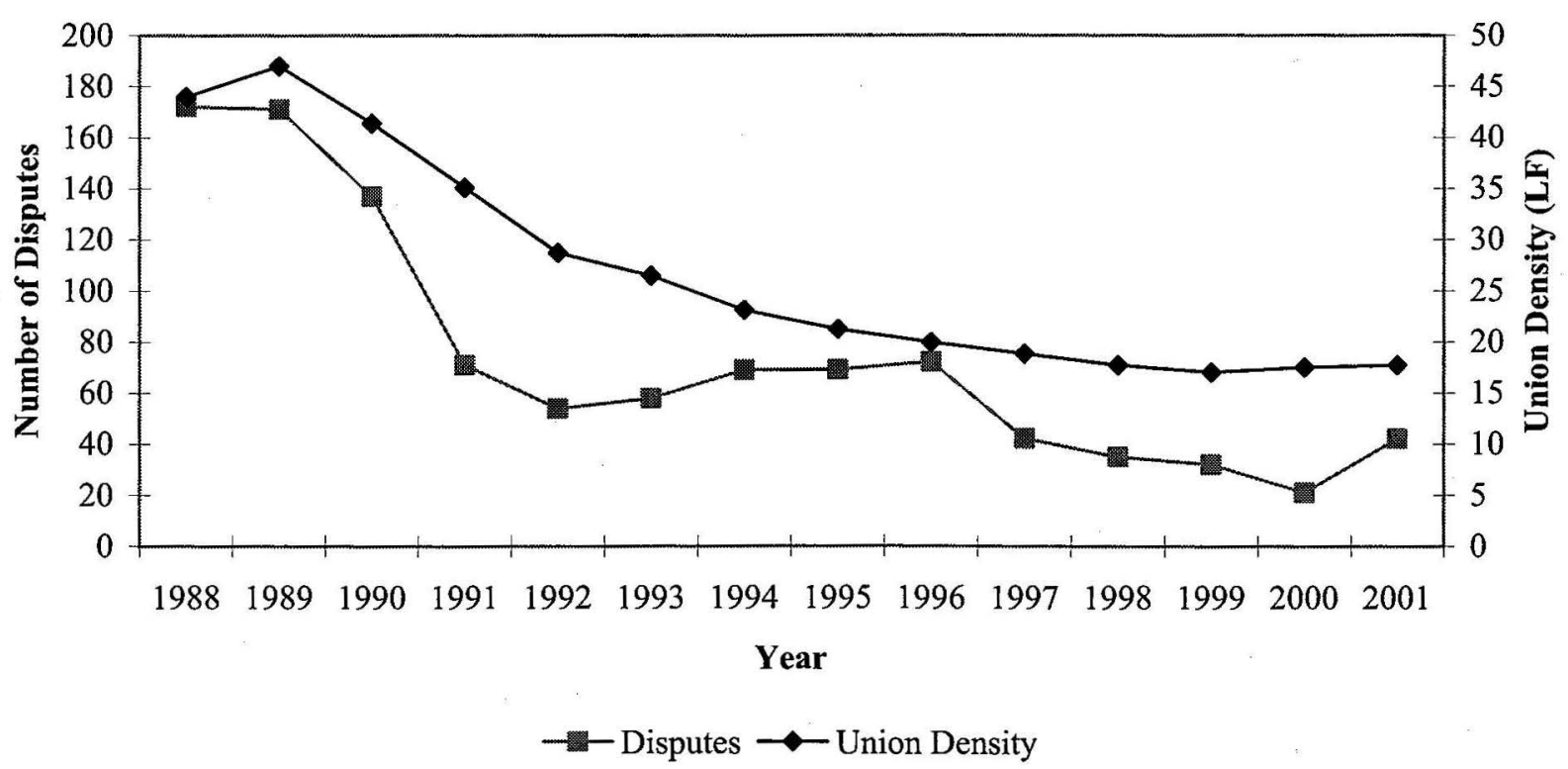


Table 2 below shows recent trends on causes of stoppages in New Zealand workplaces. The data, which allows for multiple responses, is only available for the last three years. However, is shows that between 53 and 71 percent of stoppages have been disputes over wages provisions in employment agreements - which essentially means that a quarter to a half of disputes have not been about wages. These disputes are less likely to be influenced by many of the variables analysed in this paper as disputes pertaining to wages may indeed be.

Table 2: Causes of Industrial Disputes

\begin{tabular}{c|ccccccc}
\hline Year & $\begin{array}{c}\text { Dispute arising } \\
\text { from negotiation } \\
\text { of coverage of } \\
\text { employment } \\
\text { agreement }\end{array}$ & $\begin{array}{c}\text { Dispute over } \\
\text { wage provisions } \\
\text { of employment } \\
\text { agreement }\end{array}$ & $\begin{array}{c}\text { Dispute over } \\
\text { hours of work } \\
\text { provisions of } \\
\text { employment } \\
\text { agreement }\end{array}$ & $\begin{array}{c}\text { Dispute over } \\
\text { leave } \\
\text { provisions of } \\
\text { employment } \\
\text { agreement }\end{array}$ & $\begin{array}{c}\text { Dispute over } \\
\text { overtime/shift } \\
\text { provisions of } \\
\text { employment } \\
\text { agreement }\end{array}$ & Other & Total \\
\hline 1999 & 5 & 17 & 6 &.. & 3 & 14 & 32 \\
2000 & 4 & 12 & 5 & 3 & 3 & 7 & 21 \\
2001 & 12 & 30 & 4 & 2 & 5 & 9 & 42 \\
\hline
\end{tabular}

Source: Statistics New Zealand (2002) Labour Market Statistics

Existing research on the causes and influences of industrial disputes can be broadly placed into one (or more) of three categories; those that focus on economic, institutional or sociological factors. In recent years, there have been a large number of papers examining the economic causes of industrial disputes. These either take a broad overview approach (as this paper does) or they use contract data to develop a theory on the causes of strike activity.

In 1969, Ashenfelter and Johnson wrote what has come to be considered one of the seminal works on the causes of strike activity. They write that there are three parties involved in labour-management negotiations employers, employees and union leaders. Moreover, that the motivations of the union leadership differ from the regular members (including for example, their own survival as leaders of the union). If the union leadership accept a wage offer from the employer which the employees deem insufficient, they face "the possibility that the contract will not be ratified by the membership and /or charges that they have 'sold out' to management" (1969: 37). Alternatively, Ashenfelter and Johnson propose that a strike "has the effect of lowering the rank and file's expectations due to the shock effect of the firm's resistance and the loss of normal income" (ibid). Hence, an industrial dispute could be considered an instrument to reduce the expectations of union members. Hicks (1963) on the other hand, suggests that strikes occur because of imperfect information in process of collective bargaining, or 'mistakes' due to faults in the bargaining process. He writes "the majority of actual strikes are doubtless the result of faulty negotiation" (1963: 146). He holds that when there is a large difference of opinion between the employer and the union on the length of time that the employees would be prepared to strike rather than accept a given set of terms, a deadlock is virtually inevitable.

McConnell (1990) examines the role of aggregate business, labour and product market conditions on strike incidence and duration in the United States. Findings include that strike incidence is highest in industries that are depressed relative to the rest of the economy, also that strikes are longest in industries that are booming relative to the rest of the economy. Rees (1952) suggests that strike activity may in fact be greater at times of high unemployment than at other times, because when the labour market is slack the organisation is likely to find it easier to replace striking workers and avoid interruptions to production. However, it must be emphasised that the influence of unemployment on industrial stoppages in New Zealand is likely to be much lower than in other jurisdictions. Research on the level of strike activity in the United States for example, often examines stoppages that continue for weeks - sometimes months. Where disputes continue for this length of time, employees need to find alternative sources of income. In New Zealand, the average number of days of work lost per employee is between 0.8 and 6.6 days (as shown in Table 1). It is unlikely that either striking employees will have time to find work elsewhere or employers would have time to hire and train replacement workers (which is prohibited by the Employment Relations Act).

Much of the international literature has found that work stoppages are pro-cyclical. That is, when the economy is strong, the number of work stoppages increases, and when the economy is faltering, the number of stoppages decreases. This trend is particularly evident in the United States where Rees (1952), Ashenfelter and Johnson (1969), Gunderson, Kervin and Reid (1986) and Vroman (1989) all find that strike incidence varies pro-cyclically. Ingram et al (1993) however, study strikes in British manufacturing in the $1980 \mathrm{~s}$ and contrary to U.S. experience, strikes appear to be counter cyclical - i.e. strikes increased as unemployment increased.

Gramm (1986) undertakes a -micro-level study of U.S. manufacturing data and finds that a number of factors influence strike incidence. These include the gender composition of the labour force, demand fluctuations in the product market, union density in the industry, and the extent to which wages have kept pace with inflation over the preceding contract period. On the other hand, Gramm also finds that neither the local unemployment rate when 
contract negotiations began nor the inflation rate over the term of the expiring contract influenced strike frequency or length.

Institutional and political factors, most notably the structure of the institutional relations system and the laws pertaining to when it is and is not legal to strike also play a central role in determining the frequency and length of industrial disputes. For example, Gunderson and Melino (1990) find that policy variables (such as legislation prohibiting the use or replacement workers and compulsory mediation) reduce incidence of strikes but do not, with the exception of a mandatory strike vote, reduce the length of strikes.

Sociological factors that determine whether a group of employees choose to strike are by their very nature the most difficult to measure. Furthermore, the reasons why an individual worker chooses to strike are likely to be very different in each case. For example, the labour process model of industrial disputes holds that inherent ideological conflicts between management and labour make the workplace a demanding environment. Accordingly, the best mechanism to investigate sociological explanations of industrial disputes is the case study - rather than a statistical paper. Following this line of thought Blyton and Turnbull write:

"To seek an understanding of the nature of conflict within work organisations is to grapple with a complex phenomenon. While much analysis focuses on strike statistics which provide a ready 'index' of conflict, these data can offer a misleading picture. In recent years, for example, there has been a tendency to equate the decline in officially recorded strikes with a decline (or even demise) of industrial conflict. Not only does this ignore the intensity of the conflict and bitterness of feelings involved in many strike situations, it ignores the diverse nature of both strikes and other forms of industrial conflict. ... we have therefore cautioned against any suggestion that industrial conflict has 'withered away', emphasising instead the many and varied forms of industrial conflict, the importance of both attitudes and behaviour, and the influence of a diverse range of structural, contextual and individual factors, both within the workplace and beyond. In particular, we have argued for a greater appreciation of the underlying (and continuing) sources of tension and conflict within contemporary work organisations" (1994: 294).

\section{The Model}

The statistical model employed in this paper is designed to determine the extent to which union membership and density, inflation, wages, Gross Domestic Product and the Employment Contracts Act influence the number of industrial disputes in a given industry for a given year and the total number of working days lost in each industry for each year. The following equation is illustrative of the those employed in subsequent regressions:
DISPUTES $_{\mathrm{it}}=\alpha+\beta \mathrm{UNION}_{\mathrm{it}}+\varphi \mathrm{ECA}_{\mathrm{it}}+\gamma$ INFLATION $_{\mathrm{it}}$

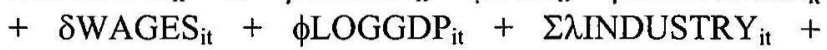
$\sum \psi \mathrm{YEAR}_{\mathrm{it}}+\varepsilon_{\mathrm{rt}}$

Where DISPUTES $_{\mathrm{it}}$ is measured as the total number of industrial disputes in a given industry $i$ at year $t$. UNION is the total number of union members in industry $i$ at time t. ECA is a dummy variable recording whether the Employment Contracts Act was in effect at the time. The other explanatory variables in equation (1) are INFLATION, as measured by change in the Consumers Price Index (base $=1000$ ), WAGES, measured by the change in the Labour Cost Index all salary and wage rates series (and the Prevailing Weekly Wage Rate Index for the years up to 1992; base=1000), LOGGDP measures the natural $\log$ of Gross Domestic Product and INUSTRY and YEAR are dummy variables accounting for the relevant industry (manufacturing, transport, storage and communication, and community, social and personal services) and year specific effects (1988 - 2000) respectively.

Equation (1) obviously contains the predicament of a relationship between two independent variables - namely union membership and the Employment Contracts Act. To overcome this problem a two-stage-least-squares model is applied for regressions 2 to 6 . The equations applied are illustrated as follows:

DISPUTES $_{i t}=\alpha+\beta{\overline{U_{N I O N}}}_{i t}+\varphi E A_{i t}+\gamma$ INFLATION $_{t}$ $+\delta$ WAGES $_{\mathrm{it}}+\phi \mathrm{GDP}_{\mathrm{it}}+\Sigma \lambda$ INDUSTRY $_{\mathrm{it}}+\Sigma \psi \mathrm{YEAR}_{\mathrm{it}}+$ $\varepsilon_{\mathrm{rt}}$

${\overline{\mathrm{UNION}_{i t}}}^{\prime} \alpha+\varphi \mathrm{ECA}_{\mathrm{it}}+\gamma \mathrm{INFLATION}_{\mathrm{t}}+\delta \mathrm{WAGES}_{\mathrm{it}}+$ $\phi \mathrm{GDP}_{\mathrm{it}}+\Sigma \lambda$ INDUSTRY $_{\mathrm{it}}+\Sigma \psi$ YEAR $_{\mathrm{it}}+\varepsilon_{\mathrm{rt}}$

Equations (2) and (3) show the two-stage-least-squares equation applied for regressions 2 to 6 . It also includes the exogenous variables pertaining to the Employment Contracts Act, change in inflation, change in wages, the natural $\log$ of GDP and the time and industry dummy variables.

In addition to the models specified in equations (1) to (3), there are two significant changes that are carried out in subsequent regressions. First, the total number of disputes is one of a number of possible dependent variables that can be used to determine the influence of macro-variables on industrial disputes. Hence, to gain a better understanding of the length of industrial stoppages, in regressions 5 and 6 we replace the number of disputes with the number of person days of work lost from industrial disputes (PERS DAYS) as the dependent variable. Second, regressions 3 to 6 replace the independent variable union membership with union density (measured as union membership as a percentage of people employed from the Household Labour Force Survey).

In carrying out the above regression model, it would be expected that union membership and union density be positively related to both the number of disputes and the number of person days lost from industrial disputes. This 
is because as the union's influence in the workplace increases their ability to barging for further benefits also increases - hence, the possibility of an industrial dispute increases. Given that the Employment Contracts Act effectively removed many of the existing benefits for employees, it would be expected that the years associated with the Employment Contracts Act would be years where industrial disputes are lower - all else being equal. Inflation essentially reduces the purchasing power of a given wage. Hence, as inflation increases, it is expected that the number of disputes will increase as employees need to make higher wage demands to maintain their current real wage. For basically the same reasons, positive changes in wages are expected to be associated with fewer work stoppages, as higher wage changes are expected to reduce the likelihood of employees being involved in an industrial stoppage. In later regressions, the difference between wage change and inflation is investigated as a potential explanatory variable. One would expect that high levels of inflation are less likely to be associated with increased disputes, if there is a corresponding high wage change. Therefore, by including the difference between wages and inflation we can ascertain whether the level of wage change is above or below the level of inflation, and specifically what the difference between the two is. We would expect that when the difference between wages change and inflation is positive the number of stoppages would be lower than when inflation is above the level of wage change - as when wage increases in above inflation the employees have effectively received a real wage increase - reducing the likelihood of going on strike. We would also expect the reverse to be the case. That is, when inflation is above the level of wage change, the employees are more likely to strike as they do not want to settle for what amounts to a real wage decrease. To test whether industrial disputes are pro-cyclical in New Zealand, the natural log of Gross Domestic Product is included as an independent variable. If industrial stoppages are indeed pro-cyclical, we would expect a positive coefficient on this variable, and of course a negative coefficient if stoppages are anticyclical.

Regression 1 uses weighted least squares to control for hetroscedasticity. As the industries are of different sizes, and have a large variation in the number of people employed one can expect non-constant variance between observations, or hetroscedasticity. To control for this, the total number of people employed (from the Household Labour Force Survey) is applied as the weight. To put it simply, this is because industries that have relatively less people employed will have a different variance of industrial stoppages than industries with relatively more employment.

The results of the first regression show the relationship between the number of disputes as the dependent variable and union membership and the Employment Contracts Act as the independent variables. Both independent variables are of the expected sign, union membership being positively related to the number of disputes and the Employment Contracts Act having a negative relationship with disputes - what's more, both are statistically significant at the one percent level of significance.
However, the obvious relationship between union membership and the introduction of the Employment Contracts Act is not controlled for in this regression. To overcome this problem subsequent regressions apply the two-stage-least-squares method to control for the relationship between these two variables.

Regression 2, as referred to above, introduces the twostage-least-squares model and also uses the total number of people employed as a weight (as do all subsequent regressions). Moreover, it also includes dummy variables to account for industry specific effects. The results in model two remain strong. Both union membership and the Employment Contracts Act have a statistically significant influence on the total number of disputes, albeit not so large as in the previous regression. Union membership has a slightly larger coefficient than in the previous regression, however, it is statistically significant at the ten percent level - rather than one percent in the first regression. The Employment Contracts Act has a slightly smaller coefficient and it too has a reduced level of significance from the one percent level to the five percent level of significance.

Regression 3 introduces other independent variables into the equation. Namely, union density is used as an instrumental variable instead of union membership. Also change in inflation, change in wages and the natural log of GDP are included as explanatory variables - in addition to year specific dummy variables. Both change in inflation and change in wages record negative coefficients, although neither are statistically significant. Somewhat surprisingly, we find that the natural log of GDP has a negative coefficient - and what's more is statistically significant at the one percent level. Why this is the case is somewhat problematic. It is most likely attributable to the somewhat poor economic performance of the New Zealand economy in the late 1980s and early 1990 s rather than a factor causing the number of stoppages to increase. Hence, positing that industrial disputes in New Zealand are anti-cyclical may be erroneous. We will investigate this issue more closely in regression 6 .

Regression 4 replaces wages and inflation with the difference between the two. The theory being that disputes will be higher when inflation is above the level of wage change, and the number of disputes will fall when wage change is higher than inflation. This is borne out by the sign and magnitude of the variable in regression 4 . Wage change less inflation is of the correct sign (negative) and is statistically significant at the one percent level. This regression is also notable because all of the other independent variables are also statistically significant. Union density is positive and statistically significant at the five percent level of significance and the period of the Employment Contracts Act remains negative and is statistically significant at the ten percent level. Note however, that the natural log of GDP remains negative and records a one percent level of significance.

One could argue that the total number of disputes is not the best dependent variable to be used in the regression. 
As discussed above it treats all stoppages equally whatever their length. For this reason, disputes has been replaced in regressions 5 and 6 with the number of person days lost from industrial disputes as the dependent variable. As with the other regressions, two-stage-leastsquares is applied to control for the relationship between union density and other independent variables, also the number of people employed is used as a weight.

Regression 5 in this paper is probably the most accurate determinant of industrial disputes, as discussed above it uses the number of person days lost from industrial disputes as the dependent variable. It includes all the independent variables applied in regression 4 and includes the difference between wages and inflation and the natural log of Gross Domestic Product. This regression suggests that union density is an influence on the number of person days lost from strikes and lockouts. It shows that for a one percentage point increase in union density, the number of industrial stoppages is likely to increase by around 7,000. This result is statistically significant at the ten percent level of significance. Furthermore, it shows that the period of the Employment Contracts Act was related to 66,000 fewer person days lost by industrial disputes. This result is statistically significant at the five percent level of significance. When the level of wage change is above the level of inflation then the number of person days lost from industrial disputes falls. This result too is statistically significant. The natural log of GDP produces a strong result, though not statistically significant.

As discussed above, the negative coefficient on the natural $\log$ of GDP is likely to be attributable to the structural and institutional difficulties of the late $1980 \mathrm{~s}$ and early $1990 \mathrm{~s}$, rather than an actual anti-cyclical relationship. To test this theory a regression similar to regression 5 has been undertaken. In this regression (6) data for the years prior to 1991 are omitted. The resulting effect is that the natural log of GDP becomes positive and is statistically significant at the ten percent level. This result adds weight to the likelihood that the negative results in earlier regressions are erroneous. Moreover, to be sure of such a relationship, one would ideally use a longer period of analysis than either 10 or 14 years. Fourteen years may be to short of a period to be sure of any cyclical pattern. Many of the U.S. studies referred to above were of a time period of twenty years or more to ensure that they included more than one cycle of economic growth.

Table Three: Regression Results

\begin{tabular}{|c|c|c|c|c|c|c|}
\hline $\begin{array}{l}\text { Regression } \\
\text { Dep Var: } \\
\text { Indep. Var: }\end{array}$ & $\begin{array}{c}\mathbf{1} \\
\text { WLS } \\
\text { DISPUTES }\end{array}$ & $\begin{array}{c}\mathbf{2} \\
\text { 2SLS } \\
\text { DISPUTES }\end{array}$ & $\begin{array}{c}\mathbf{3} \\
\text { 2SLS } \\
\text { DISPUTES }\end{array}$ & $\begin{array}{c}4 \\
\text { 2SLS } \\
\text { DISPUTES }\end{array}$ & $\begin{array}{c}\mathbf{5} \\
\text { 2SLS } \\
\text { PERS_DAYS }\end{array}$ & $\begin{array}{c}\mathbf{6} \\
\text { 2SLS } \\
\text { PERS_DAYS }\end{array}$ \\
\hline UNION & $\begin{array}{r}0.080^{\mathrm{a}} \\
(0.029)\end{array}$ & $\begin{array}{r}0.111^{\mathrm{c}} \\
(0.062)\end{array}$ & & & & \\
\hline DENSITY & & & $\begin{array}{r}2.586^{\mathrm{c}} \\
(1.418)\end{array}$ & $\begin{array}{c}1.805^{b} \\
(0.868)\end{array}$ & $\begin{array}{r}7.030^{\mathrm{c}} \\
(3.839)\end{array}$ & $\begin{array}{r}2.735 \\
(1.914)\end{array}$ \\
\hline ECA & $\begin{array}{r}-13.814^{\mathrm{a}} \\
(3.899)\end{array}$ & $\begin{array}{r}-11.888^{b} \\
(4.981)\end{array}$ & $\begin{array}{l}-39.229 \\
(25.17)\end{array}$ & $\begin{array}{r}-13.037^{\mathrm{c}} \\
(6.742)\end{array}$ & $\begin{array}{l}-66.491^{b} \\
(29.803)\end{array}$ & \\
\hline LOG_GDP & & & $\begin{array}{r}-31.357 \\
(19.099)\end{array}$ & $\begin{array}{l}-32.566^{\mathrm{a}} \\
(11.731)\end{array}$ & $\begin{array}{r}-74.382 \\
(51.860)\end{array}$ & $\begin{array}{r}55.094^{\mathrm{c}} \\
(27.971)\end{array}$ \\
\hline $\begin{array}{l}\text { WAGES } \\
\text { INFLATION }\end{array}$ & & & $\begin{array}{r}-0.780 \\
(6.425) \\
-7.438 \\
(6.338)\end{array}$ & & & \\
\hline WGE-INFL & & & & $\begin{array}{l}-1.262^{\mathrm{a}} \\
(0.286)\end{array}$ & $\begin{array}{l}-5.259^{\mathrm{a}} \\
(1.264)\end{array}$ & $\begin{array}{r}-0.593 \\
(0.646)\end{array}$ \\
\hline IND DUM & None & 3 & 3 & 3 & 3 & 3. \\
\hline TIME DUM & None & None & 13 & 13 & 13 & 10 \\
\hline WEIGHT & Employed & Employed & Employed & Employed & Employed & Employed \\
\hline CONSTANT & 18.968 & 13.060 & 355.894 & 1580.623 & 5889.738 & -32.223 \\
\hline ADJ R2 & 0.3964 & 0.5543 & 0.4674 & 0.7480 & 0.5024 & 0.3963 \\
\hline $\mathrm{N}$ & 56 & 56 & 56 & 56 & 56 & 43 \\
\hline $\begin{array}{l}\text { Standard erro } \\
\text { Level of sign }\end{array}$ & ntheses & & & & & \\
\hline
\end{tabular}




\section{Discussion}

The decline in industrial disputes in recent years very much matches the decline in union membership and union density. This result continues even after controlling for any influence the Employment Contracts Act has had on union membership and density.

The Employment Contracts Act was, not surprisingly, a negative influence in the level of stoppage actively. This result was statistically significant in all regressions apart from number 4.

Economic growth, as measured by the natural $\log$ of Gross Domestic Product, has not turned out to be a particularly useful variable in explaining the decline in industrial stoppages. This could be because either Gross Domestic Product has had no effect on disputes (which would go against international evidence) or most likely because the period of this analysis is too short to make any substantive conclusion as to its applicability.

This paper has shown that the difference between the change in wage levels and inflation is also a statistically significant influence in both the number of disputes and the number of person days lost from industrial disputes. This result is consistent with Gramm's 1986 paper refereed to earlier. Inflation on its own is not a statistically significant determinant on the level of industrial stoppage activity. It is whether wages have kept pace with inflation that influences the level of industrial disputes.

Other factors are also likely to have influenced the level of industrial stoppages over the past fourteen years that are not referred to in the above analysis. For example, the industries that have shown the greatest relative decline in employment in recent years, such as the manufacturing industry, have been the industries which traditionally have had a high level of industrial disputes. Richard Hyman, writing about the decline of strikes in the U.K. has suggested that "these are the areas of employment which have declined most sharply in recent decades; whereas employment has grown in sectors without a tradition of collective militancy" (1999). Similarly, these same industries are now much more open to international competition than they have been in the past. Again, Hyman writes "[the] priority of survival in an ever more competitive world reinforces the pursuit of peaceful solutions"(ibid).

\section{Further Research}

This paper merely begins to tell the story on the influences on industrial disputes. The reasons why employees choose to strike are many and varied. Accordingly, there is a great deal of opportunity for further research on this topic in the New Zealand environment. Such opportunities include the use of collective bargaining records to ascertain the reasons for disputes in individual workplaces. Similarly, case studies and interviews of key stakeholders provide the opportunity to investigate the root causes of industrial disputes in the workplace. Such industry and case study analysis will aid the development of a comprehensive picture of the causes and reasons for industrial disputes in New Zealand.

\section{Notes}

1. This study is part of a larger project which receives funding from the Public Good Science Fund administered by the Foundation for Research, Science and Technology (Contract no. VIC903).

2. The industrial dispute statistics in this paper exclude work stoppages in which less than five person days of work were lost (prior to 2000 stoppages of less than ten person days of work were excluded from official statistics).

\section{References}

Ashenfelter, O. and Johnson, G. (1969) Bargaining Theory, Trade Unions and Industrial Strike Activity, American Economic Review, 59, 1, 3549.

Blyton, P. and Turnbull, P. (1994) The Dynamics of Employee Relations, London: MacMillan Press.

Gramm, C. (1986) The Determinants of Strike Incidence and Severity: A Micro-Level Study, Industrial and Labor Relations Review, 39, 3, 361-376.

Gramm, C., Hendricks, W. and Kahn, L. (1988) Inflation Uncertainty and Strike Activity, Industrial Relations, 27, 1, 114-129.

Gunderson, M., Kervin, J. and Reid, F. (1986) Logit Estimation of Strike Incidence form Canadian Contract Data, Journal of Labour Economics, 4, 2 , 257-276.

Gunderson, M. and Melino, A. (1990) The Effects of Public Policy on Strike Duration, Journal of Labor Economics, 8, 3, 295-316.

Harrison, A. and Stewart. M. (1994) Is Strike Behavior Cyclical? Journal of Labour Economics, 12, 4, 524-553.

Hicks, J. (1963) The Theory of Wages, London: MacMillan and Co.

Hyman, R. (1977) Strikes, 2nd edition, Glasgow: William Collins \& Sons.

Hyman, R. (1999) Strikes in the UK: withering away?, european industrial relations observatory online, http://www.eiro.eurofound.ie/1999/07/feature/UK 9907215F.html, accessed 1 November 2002. 
Ingram, P., Metcalf, D. and Wadsworth, J. (1993) Strike Incidence in British Manufacturing in the 1980s, Industrial and Labor Relations Review, 46, 4, 704-717.

Kaufman, B. (1983) The Determinants of Strikes Over Time and Across Industries, Journal of Labor Research, 4, 2, 159-175.

Kaufman, B., Skeels, J., Paldam, M. and Pedersen, P. (1984) Replies, Industrial and Labor Relations Review, 37, 2, 269-278.

McConnell, S. (1990) Cyclical Fluctuations in Strike Activity, Industrial and Labor Relations Review, 44, 1, 130-143.
Rees, A. (1952) Industrial Conflict and Business Fluctuations, Journal of Political Economy, 60, 5, 371-385.

Statistics New Zealand (various years) Labour Market Statistics, Wellington: Statistics New Zealand.

Vroman, S. (1989) A Longitudinal Analysis of Strike Activity in U.S. Manufacturing: 1957 - 1984, American Economic Review, 79, 4, 816-826.

Wheeler, H. (1984) Comment: Determinants of Strikes, Industrial and Labor Relations Review, 37, 2, 263269. 